\title{
Plasma Insulin Responses to Oral and Intravenous Glucose: Studies in Normal and Diabetic Subjects*
}

\author{
Michael J. Perley $\$$ and David M. Kipnis \\ (From the Department of Medicine, Washington University School of Medicine, \\ St. Louis, Missouri)
}

\begin{abstract}
The plasma insulin responses of normal weight and obese, diabetic, and nondiabetic subjects to intravenous glucose was only $30-40 \%$ of that seen after oral glucose, indicating that alimentary mechanism(s) in addition to the arterial blood sugar concentration regulate insulin secretion. Observations made in subjects with diverted portal circulation indicate that the alimentary insulinogenic mechanism is located in the intestinal tract. The insulinogenic potency of the alimentary and glycemic stimuli expressed in terms of insulin secretion per gram of glucose were remarkably similar within each group of individuals. Between these groups, however, there were considerable differences. Obesity, with or without associated diabetes, was associated with a true hypersecretory responsiveness, whereas diabetes was characterized, with or without obesity, by a marked impairment in insulin secretion. The experimental design used in these studies permitted quantitation of the magnitude of the glycemic component of an oral glucose load. As a consequence of impaired insulin secretion, a greater than normal proportion of the oral glucose load escapes initial hepatic extraction in the maturity-onset diabetic and enters the peripheral circulation. Therefore, in the noninsulin-requiring maturity-onset diabetic, the glycemic insulinogenic stimulus for a given oral glucose load is significantly greater than in normal subjects and accounts for the excessive plasma insulin responses observed late in the course of an oral glucose tolerance test.
\end{abstract}

\section{Introduction}

Recent studies have indicated that factor(s) other than the arterial blood glucose level may also play an important role in determining the insulin secretory activity of the pancreatic beta cell. It has been reported, for example, that the plasma insulin response to oral glucose exceeds that ob-

* Received for publication 30 June 1967 and in revised form 27 July 1967.

This study was supported by U. S. Public Health Service grants AM-1921, AM 5105, and FR-36, and was presented in part at the meeting of the Central Society of Clinical Research, 5 November 1965, Chicago, Ill.

$\ddagger$ Trainee in Metabolism; present address : Department of Endocrinology, Lovelace Clinic, Albuquerque, N. Mex.

Address requests for reprints to Dr. David M. Kipnis, Department of Medicine, Washington University School of Medicine, Metabolism Division, 4949 Barnes Hospital Plaza, St. Louis, Mo. 63110. served after the intravenous administration of the same glucose load, suggesting that the intestinal absorption of glucose triggers insulin release by a mechanism independent of changes in the arterial glucose level $(1-4)$. The experimental designs used in these studies have not permitted quantitative estimates of the relative insulinogenic effects of the arterial blood glucose level and the alimentary mechanism(s) in regulating insulin secretion under physiological and pathological conditions. Such estimates are necessary in order to assess, for example, the importance of differing blood sugar levels as a determinant in the excessive plasma insulin responses to oral glucose observed in many patients with obesity and adult-onset diabetes mellitus. The present study was undertaken to quantitate the differential insulinogenic contributions of the blood sugar level and alimen- 
TABLE I

Classification of patients on basis of weight and carbohydrate tolerance

\begin{tabular}{|c|c|c|c|c|c|c|}
\hline \multirow[b]{2}{*}{ Group } & \multirow[b]{2}{*}{ No. } & \multirow[b]{2}{*}{ Age } & \multirow[b]{2}{*}{$\%$ of ideal wt* } & \multicolumn{3}{|c|}{ Blood sugar response to GTT } \\
\hline & & & & Fasting & $1 \mathrm{hr}$ & $2 \mathrm{hr}$ \\
\hline $\begin{array}{l}\text { Normal } \\
\text { Obese } \\
\text { Normal wt diabetic } \\
\text { Obese diabetic }\end{array}$ & $\begin{array}{l}50 \\
12 \\
19 \\
16\end{array}$ & $\begin{array}{l}11-61 \\
14-62 \\
24-69 \\
15-65\end{array}$ & $\begin{array}{r}90-115 \\
168-412 \\
95-115 \\
177-350\end{array}$ & $\begin{array}{l}m g / 100 m l \\
<90 \\
<90 \\
80-120 \\
80-150\end{array}$ & $\begin{array}{c}m g / 100 m l \\
<140 \\
<140 \\
>170 \\
>170\end{array}$ & $\begin{array}{c}m g / 100 m l \\
<110 \\
<110 \\
>140 \\
>140\end{array}$ \\
\hline
\end{tabular}

* Based on Metropolitan_Life Insurance Tables, 1959.

tary mechanisms in normal weight and obese nondiabetic and diabetic subjects. This was accomplished by determining the plasma insulin secretory responses to oral glucose and following intravenous glucose infusions which reproduced the oral glucose blood sugar levels.

\section{Methods}

Subjects. Subjects were divided into four groups based on their weight and response to a $100 \mathrm{~g}$ oral glucose tolerance test (Table I). All obese individuals were at least $60 \%$ overweight and none of the diabetic subjects had ever received either insulin or oral hypoglycemic agents. All subjects were tested after an overnight fast (14-18 hr) and had been on a diet estimated to contain in excess of $250 \mathrm{~g}$ of carbohydrate daily.

Procedures. Each individual served as his own control when the plasma insulin response to oral versus intravenous glucose was compared. This comparison was accomplished by reproducing with a glucose infusion the venous blood sugar profile observed during the first $3 \mathrm{hr}$ after oral ingestion of $100 \mathrm{~g}$ of glucose. The oral glucose load ( $\mathrm{g} / \mathrm{kg}$ body weight) was calculated by assuming complete absorption of glucose from the gastrointestinal tract over a $3 \mathrm{hr}$ period. Complete gastric emptying of the oral glucose load was confirmed in 10 normal, 3 obese nondiabetic, 4 normal weight diabetic, and 3 obese diabetic subjects by intubation with a nasogastric tube under fluoroscopic observation $3 \mathrm{hr}$ after ingestion of $100 \mathrm{~g}$ of glucose. The tip of the tube was placed at the pyloric junction, and $50 \mathrm{ml}$ of saline was injected and rapidly withdrawn. Protein-free filtrates (5) of the aspirate were prepared immediately after aspiration and the amount of glucose was determined by the glucose oxidase procedure. Less than $500 \mathrm{mg}$ of glucose was found in the gastric washings in all subjects.

Infusion experiments were performed in the following manner: a $20 \%$ solution of glucose was infused with a variable speed Harvard pump into an antecubital vein while the blood sugar level was monitored in a continuous stream of blood introduced into an Autoanalyzer circuit $(6,7)$ from an indwelling venous catheter in the contralateral arm. The Autoanalyzer system gave a completed chemical analysis within $6 \mathrm{~min}$ after aspiration of blood. The volume of blood aspirated was $0.18 \mathrm{ml} / \mathrm{min}$; clotting was prevented by the admixture of heparin sodium at a constant rate into the aspirated stream of blood. "Normal" and "diabetic" blood glucose profiles, representing the mean responses of 50 normal and 35 mildly diabetic subjects to $100 \mathrm{~g}$ oral glucose, were reproduced by glucose infusion in both normal and diabetic subjects in order to compare the plasma insulin responses of these individuals at comparable blood sugar levels. Infused glucose loads were calculated by subtracting from the amount of glucose infused the quantity of glucose excreted in the urine during the course of the infusion. Urinary glucose was measured by the hexokinase-glucose- 6 phosphate dehydrogenase system (8) using urine specimens diluted $1: 50$ with distilled water. With this procedure, 50 normal urine specimens treated with glucose oxidase to remove all glucose gave background values of less than $2 \mathrm{mg} / 100 \mathrm{ml}$.

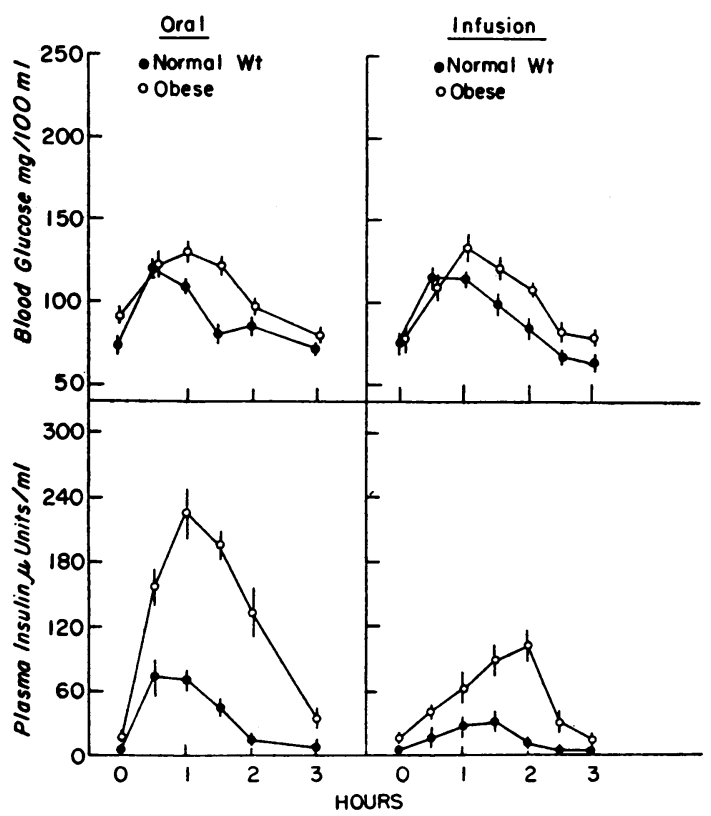

Fig. 1. Plasma insulin Responses of 18 normal WEIGHT AND 12 OBESE NONDIABETIC SUBJECTS TO ORAL GLUCOSE (100 g) AND INFUSION MAINTAINED NORMAL BLOOD GLUCOSE PROFILE. Values represent the mean \pm SEM. 
TABLE II

Mean integrated plasma insulin responses of normal weight and obese diabetic and nondiabetic subjects to oral and infused glucose

\begin{tabular}{|c|c|c|c|c|}
\hline \multirow[b]{2}{*}{ Subjects } & \multicolumn{2}{|c|}{ Oral glucose } & \multicolumn{2}{|c|}{ Infused glucose } \\
\hline & Normal & Diabetic & Normal profile & Diabetic profile \\
\hline & \multicolumn{2}{|c|}{$\mu U-\min m l^{-1}$} & \multicolumn{2}{|c|}{$\mu U-\min m l^{-1}$} \\
\hline $\begin{array}{l}\text { Normal }(18)^{*} \\
\text { Obese (12) } \\
\text { Normal wt diabetic (12) } \\
\text { Obese diabetic (12) }\end{array}$ & $\begin{aligned} 7,580 & \pm 1,020 \ddagger \\
24,582 & \pm 3,142 \\
& -\end{aligned}$ & $\begin{array}{c}- \\
5,472 \pm 650 \\
11,628 \pm 1,280\end{array}$ & $\begin{array}{c}2,088 \pm 146 \\
7,524 \pm 1,472 \\
565 \pm 108 \\
2,988 \pm 249\end{array}$ & $\begin{aligned} 7,416 & \pm 990 \\
28,480 & \pm 1,710 \\
2,124 & \pm 242 \\
5,112 & \pm 563\end{aligned}$ \\
\hline
\end{tabular}

* Number of subjects.

$\ddagger$ Mean \pm SEM.

Arterial blood glucose levels were estimated by measuring the blood glucose content of "arterialized capillary blood" obtained by finger puncture after immersing the extremity in warm water for $5 \mathrm{~min}$. Plasma insulin levels were determined by the double antibody immunoassay method of Morgan and Lazarow (9). Since methods have not been devised for the direct measurement of total pancreatic insulin release in man, the area circumscribed by the plasma insulin curve and expressed as $\mu$ units-minutes $\mathrm{ml}^{-1}$ has been used as an index for comparing rela- tive quantitative changes of insulin secretion in the same individual and between groups of subjects.

\section{Results}

Plasma insulin responses of normal weight and obese nondiabetic subjects to oral and intravenous glucose. The plasma insulin levels and integrated insulin secretory responses of 18 normal weight

TABLE III

Comparable venous and arterialized capillary blood sugar and plasma insulin levels after oral and intravenous glucose loads

\begin{tabular}{|c|c|c|c|c|c|c|c|c|c|c|c|c|c|c|c|}
\hline \multirow[b]{2}{*}{ Subject } & \multirow[b]{2}{*}{ Minutes } & \multicolumn{6}{|c|}{ Oral glucose } & \multirow{2}{*}{$\underset{\text { glucose* }}{\mathbf{N} \mathrm{A}-\mathrm{V}}$} & \multicolumn{6}{|c|}{ Intravenous glucose } & \multirow{2}{*}{$\underset{\text { glucose* }}{\sum \mathrm{A}-\mathrm{V}}$} \\
\hline & & 0 & 30 & 60 & 90 & 120 & 180 & & 0 & 30 & 60 & 90 & 120 & 180 & \\
\hline & & & & & & & & $\stackrel{\mathrm{mg} /}{100 \mathrm{ml}}$ & & & & & & & $\stackrel{m g /}{100 \mathrm{ml}}$ \\
\hline C. B. & $\begin{array}{l}\text { Cap } \\
\text { Ven }\end{array}$ & $\begin{array}{l}90 \\
70\end{array}$ & $\begin{array}{l}144 \\
110\end{array}$ & $\begin{array}{r}107 \\
80\end{array}$ & $\begin{array}{l}90 \\
80\end{array}$ & $\begin{array}{r}103 \\
84\end{array}$ & $\begin{array}{l}68 \\
49\end{array}$ & 129 & $\begin{array}{l}94 \\
88\end{array}$ & $\begin{array}{l}146 \\
127\end{array}$ & $\begin{array}{l}117 \\
110\end{array}$ & $\begin{array}{r}104 \\
89\end{array}$ & $\begin{array}{l}96 \\
81\end{array}$ & $\begin{array}{l}64 \\
57\end{array}$ & 69 \\
\hline Insulin§ & & 8 & 70 & 35 & 38 & 28 & 4 & & 4 & 10 & 25 & 8 & 2 & 0 & \\
\hline D. S. & $\begin{array}{l}\text { Cap } \\
\text { Ven }\end{array}$ & $\begin{array}{r}105 \\
95\end{array}$ & $\begin{array}{l}188 \\
157\end{array}$ & $\begin{array}{l}136 \\
123\end{array}$ & $\begin{array}{l}144 \\
110\end{array}$ & $\begin{array}{l}143 \\
124\end{array}$ & $\begin{array}{l}62 \\
51\end{array}$ & 118 & $\begin{array}{r}106 \\
92\end{array}$ & $\begin{array}{l}163 \\
149\end{array}$ & $\begin{array}{l}145 \\
134\end{array}$ & $\begin{array}{l}127 \\
112\end{array}$ & $\begin{array}{l}123 \\
112\end{array}$ & $\begin{array}{l}102 \\
100\end{array}$ & 67 \\
\hline Insulin & & 13 & 128 & 66 & 63 & 49 & 13 & & 9 & 13 & 20 & 11 & 13 & 5 & \\
\hline C. B. & $\begin{array}{l}\text { Cap } \\
\text { Ven }\end{array}$ & $\begin{array}{l}99 \\
96\end{array}$ & $\begin{array}{l}142 \\
132\end{array}$ & $\begin{array}{l}121 \\
111\end{array}$ & $\begin{array}{l}145 \\
123\end{array}$ & $\begin{array}{l}133 \\
119\end{array}$ & $\begin{array}{r}114 \\
93\end{array}$ & 80 & $\begin{array}{l}91 \\
89\end{array}$ & $\begin{array}{l}133 \\
139\end{array}$ & $\begin{array}{l}141 \\
132\end{array}$ & $\begin{array}{l}129 \\
120\end{array}$ & $\begin{array}{l}124 \\
115\end{array}$ & $\begin{array}{l}110 \\
101\end{array}$ & 38 \\
\hline Insulin & & 8 & 27 & 23 & 23 & 18 & 5 & & 2 & 14 & 19 & 11 & 13 & 9 & \\
\hline $\begin{array}{l}\text { P.P. } \\
\text { Glucose }\end{array}$ & $\begin{array}{l}\text { Cap } \\
\text { Ven }\end{array}$ & $\begin{array}{l}99 \\
95\end{array}$ & $\begin{array}{l}170 \\
152\end{array}$ & $\begin{array}{l}145 \\
118\end{array}$ & $\begin{array}{r}117 \\
94\end{array}$ & $\begin{array}{l}132 \\
110\end{array}$ & $\begin{array}{l}73 \\
69\end{array}$ & 98 & $\begin{array}{l}97 \\
86\end{array}$ & $\begin{array}{l}171 \\
151\end{array}$ & $\begin{array}{l}154 \\
156\end{array}$ & $\begin{array}{l}148 \\
132\end{array}$ & $\begin{array}{l}117 \\
111\end{array}$ & $\begin{array}{l}82 \\
71\end{array}$ & 64 \\
\hline Insulin & & 10 & 61 & 49 & 52 & 31 & 4 & & 4 & 24 & 28 & 25 & 24 & 6 & \\
\hline P.T. & $\begin{array}{l}\text { Cap } \\
\text { Ven }\end{array}$ & $\begin{array}{l}85 \\
83\end{array}$ & $\begin{array}{l}171 \\
145\end{array}$ & $\begin{array}{l}142 \\
118\end{array}$ & $\begin{array}{l}143 \\
107\end{array}$ & $\begin{array}{l}126 \\
102\end{array}$ & $\begin{array}{r}103 \\
84\end{array}$ & 131 & $\begin{array}{l}88 \\
72\end{array}$ & $\begin{array}{l}175 \\
151\end{array}$ & $\begin{array}{l}136 \\
134\end{array}$ & $\begin{array}{l}134 \\
130\end{array}$ & $\begin{array}{r}117 \\
96\end{array}$ & $\begin{array}{l}98 \\
89\end{array}$ & 76 \\
\hline Insulin & & 10 & 80 & 50 & 47 & 29 & 18 & & 9 & 32 & 59 & 29 & 17 & 9 & 9 \\
\hline
\end{tabular}

* Represents the sum of the A-V glucose differences at the various times tested.

$\ddagger$ Capillary (Cap) and venous (Ven) blood sugar are in $\mathrm{mg} / 100 \mathrm{ml}$.

$\$$ Venous plasma insulin, $\mu \mathrm{U} / \mathrm{ml}$. 
and 12 obese nondiabetic individuals after oral glucose and glucose infusions are shown in Fig. 1 and Table II. The plasma insulin responses to intravenous glucose of both normal and obese subjects averaged between 30 and $40 \%$ of those seen after oral glucose ingestion. The pattern of response also appeared to differ in that maximal plasma insulin levels were reached earlier after oral glucose ingestion (30-60 $\mathrm{min})$ than after intravenous infusion ( $90-120 \mathrm{~min})$, despite the fact that peak blood sugar levels occurred at the same time under both conditions. Obese subjects secreted 3-5 times more insulin than normal weight subjects $(P<0.001)$ after both oral glucose ingestion and intravenous glucose infusion.

It was assumed in these studies that duplication with glucose infusion of the venous blood sugar levels observed after oral glucose ingestion also resulted in the development of a comparable arterial blood glucose profile. This proved to be the case in five normal individuals in whom both arterialized capillary and venous blood sugar levels were measured during both oral glucose and glucose infusion (Table III). In these subjects, as well as the individuals recorded in Fig. 1, the

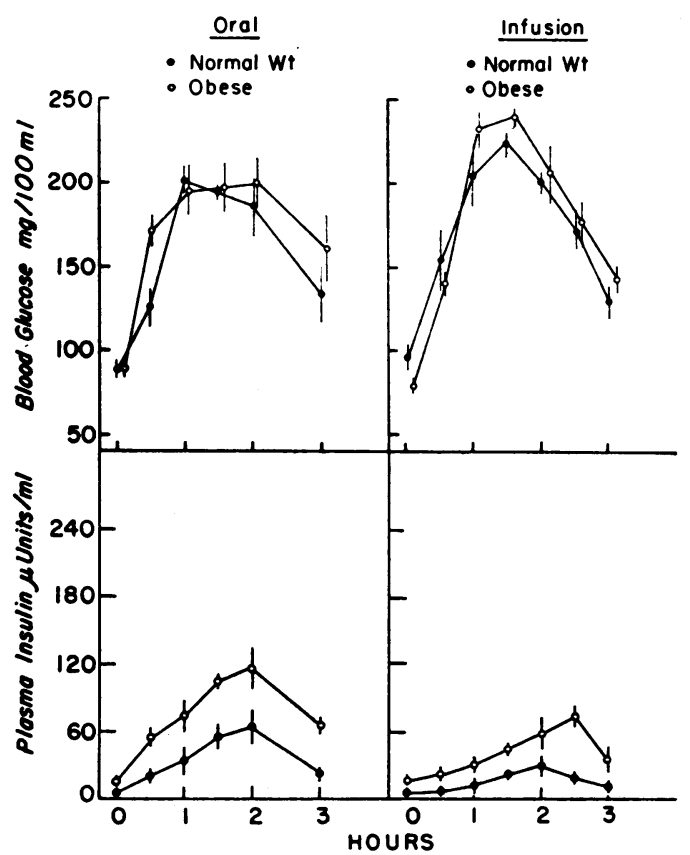

Fig. 2. Plasma insulin Responses of 12 NORMAL WEIGHT AND 12 OBESE DIABETIC SUBJECTS TO ORAL GLUCOSE $(100 \mathrm{~g})$ AND INFUSION MAINTAINED DIABETIC BLOOD GLUCOSE PROFILE. Values represent the mean \pm sEM.

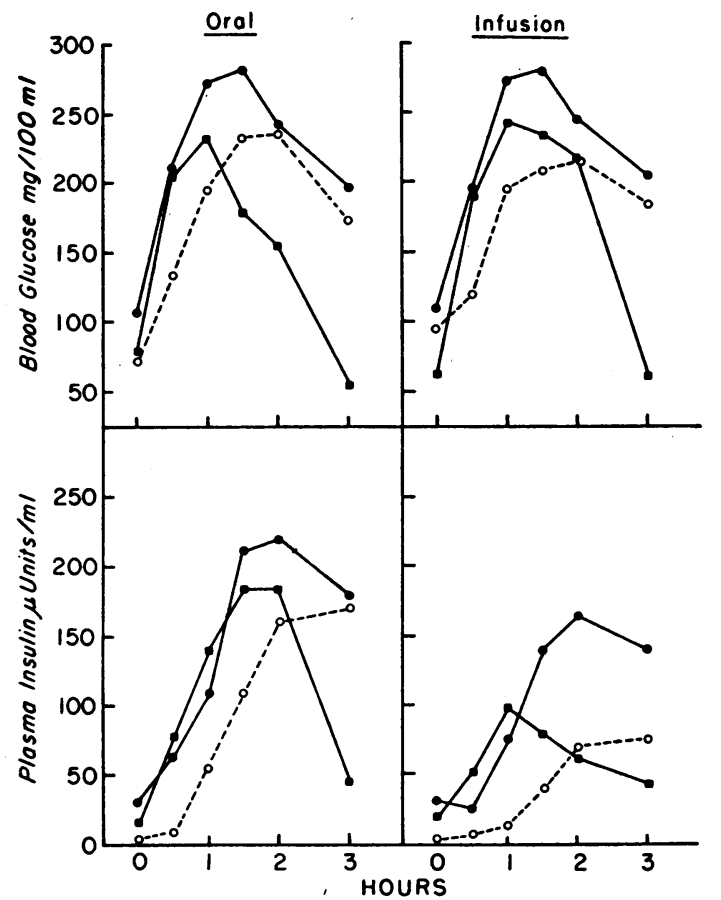

Fig. 3. Plasma insulin responses of two subjects WITH END-TO-SIDE PORTACAVAL SHUNTS $(\bullet, \square)$ AND ONE PATIENT WITH SEVERE CIRRHOSIS AND PORTAL HYPERTENSION (O) TO ORAL GLUCOSE (100 g) VERSUS INFUSION MAINTAINED COMPARABLE BLOOD GLUCOSE PROFILE.

venous glucose levels attained were slightly higher during the glucose infusion procedure than after oral glucose ingestion. Under these conditions, the arterialized capillary glucose levels during both test procedures were remarkably similar. Nevertheless, the plasma insulin secretory response in these individuals after intravenous glucose $(2644 \pm 162$ $\mu \mathrm{U}$-min $\mathrm{ml}^{-1}$ ) was less than $40 \%$ of that after glucose ingestion $\left(7688 \pm 962 \mu \mathrm{U}-\min \mathrm{ml}^{-1}\right)$. As might be expected from the plasma insulin response, the rate of peripheral glucose utilization also appeared to be more rapid after oral glucose. Thus, if the sum of the A-V differences at the various time periods measured is used as an index of the relative rates of peripheral glucose utilization (Table III), glucose uptake after oral glucose ingestion $(111 \pm 9 \mathrm{mg} / 100 \mathrm{ml})$ was $76 \%$ faster than that after glucose infusion $(63 \pm 8 \mathrm{mg} / 100$ ml), $P<0.005$.

Plasma insulin responses of normal weight and obese diabetic subjects to oral and intravenous glucose. In 12 normal weight and 12 obese diabetic individuals in whom the oral blood glucose 


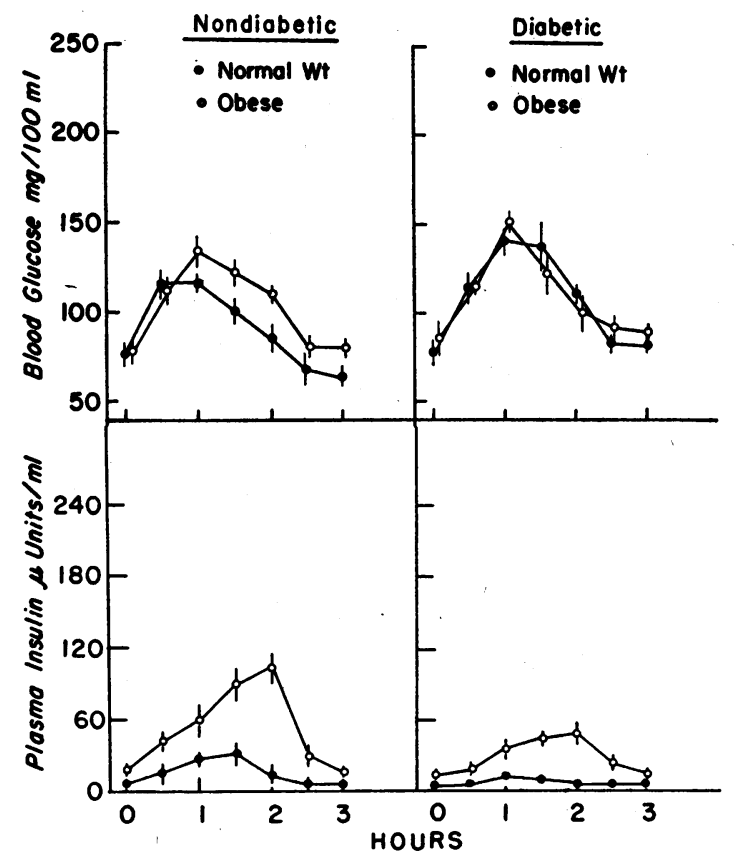

Fig. 4. Plasma insulin Responses of 15 nORMal, 12 OBESE NONDIABETIC, 12 NORMAL WEIGHT DIABETIC, AND 12 OBESE DIABETIC SUBJECTS TO INFUSION MAINTAINED NORMAL BLOOD GLUCOSE PROFILE. Values represent mean \pm SEM.

profile was reproduced by glucose infusion, the plasma insulin responses to oral glucose were 2-3 times greater $(P<0.005)$ than those observed after intravenous glucose (Fig. 2, Table II). This differential insulin response occurred despite the fact that the peak mean blood sugar level reached 90 min after beginning the infusion procedure was almost $20 \%$ higher than that attained after oral ingestion in both diabetic groups. Even in these diabetic individuals, obesity was still associated with a significantly greater insulin secretory response to both oral and infused glucose $(P<$ 0.01 ).

Plasma insulin responses to oral and intravenous glucose in subjects with diverted portal circulation. In two individuals with end-to-side portacaval shunts established 8-12 yr previously because of severe intrahepatic portal vein obstruction and in one patient with severe portal hypertension and extensive collateral circulation resulting from advanced Laennec's cirrhosis, insulin secretion was 2-3 times greater after oral glucose ingestion than after glucose infusion. Furthermore, all three patients showed the same delayed pattern of response to intravenous glucose as noted in normal and diabetic subjects (Fig. 3).

Although each of these subjects exhibited a diabetic oral glucose tolerance response, the infusion glucose load required to reproduce their abnormal oral glucose tolerance curves $(1.18 \mathrm{~g} / \mathrm{kg}$ body weight) closely approximated the infusion load used to establish a "diabetic" blood glucose profile in normal individuals $(1.64 \mathrm{~g} / \mathrm{kg}$ body weight) and was significantly greater than the load given either normal weight or obese diabetic subjects ( 0.72 and $0.54 \mathrm{~g} / \mathrm{kg}$, respectively ; see Table IV). Furthermore, the plasma insulin responses in these patients to both oral glucose (18,$\left.852 \mu \mathrm{U}-\mathrm{min} \mathrm{ml}^{-1}\right)$ and infused glucose $(9681 \mu \mathrm{U}$ $\min \mathrm{ml}^{-1}$ ) were considerably greater than the responses observed in normal weight and obese diabetic subjects at comparable blood sugar levels.

Plasma insulin responses to infused "normal" and "diabetic" blood glucose profiles. The plasma insulin levels and integrated insulin secretory responses of 15 normal, 12 obese nondiabetic, 12 normal weight diabetic, and 12 obese diabetic sub-

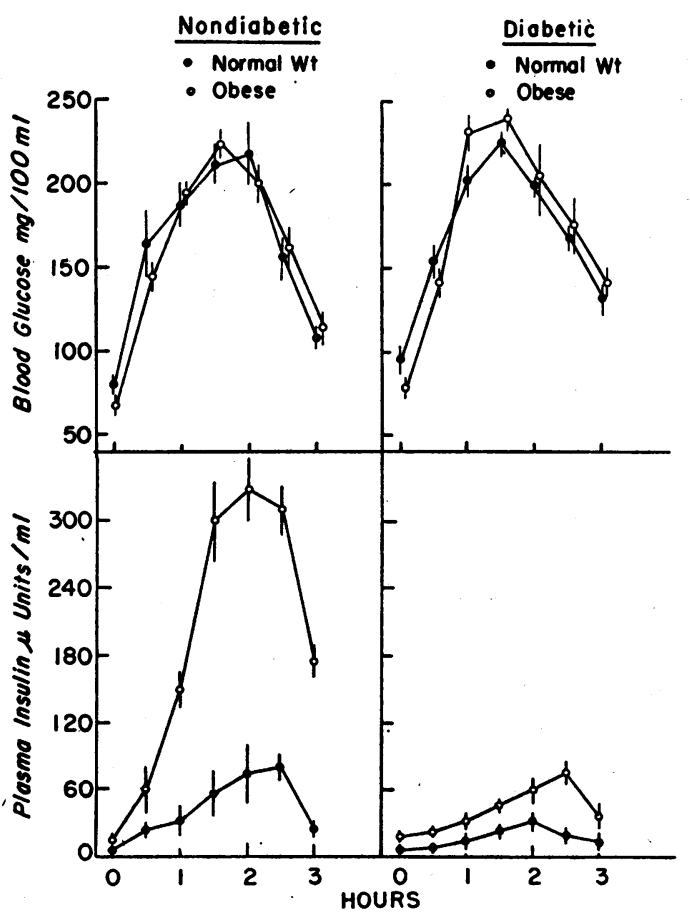

Fig. 5. Plasma insulin Responses of 12 NORMal, 12 OBESE NONDIABETIC, 12 NORMAL WEIGHT DIABETIC, AND 11 OBESE DIABETIC SUBJECTS TO INFUSION MAINTAINED DIABETIC BLOOD GLUCOSE PROFILE. Values represent mean \pm SEM. 
TABLE IV

Intravenous glucose loads required to produce normal and diabetic blood glucose profiles in normal and obese nondiabetic and diabetic subjects

\begin{tabular}{|c|c|c|c|c|c|}
\hline \multirow[b]{2}{*}{ Subjects } & \multirow[b]{2}{*}{$\mathrm{Wt}$} & \multicolumn{2}{|c|}{ Normal glucose profile } & \multicolumn{2}{|c|}{ Diabetic glucose profile } \\
\hline & & $\begin{array}{l}\text { Total glucose } \\
\text { infused }\end{array}$ & $\underset{\text { load }}{\text { Glucose }}$ & $\begin{array}{c}\text { Total glucose } \\
\text { inf used }\end{array}$ & $\begin{array}{l}\text { Glucose } \\
\text { load }\end{array}$ \\
\hline Normal $(18)^{*}$ & $71.3^{\mathrm{kg}} \pm 8.0 \ddagger$ & $31.9^{g} \pm 1.1$ & $\begin{array}{l}g / k g \text { body wt } \\
0.46 \pm 0.02\end{array}$ & $116.1^{g} \pm 12.8$ & $\begin{array}{l}g / k g \text { body } w t \\
1.64 \pm 0.18\end{array}$ \\
\hline $\begin{array}{l}\text { Obese } \\
\quad \text { nondiabetic (12) }\end{array}$ & $144.3 \pm 14.6$ & $35.9 \pm 3.3$ & $0.25 \pm 0.05$ & $125.6 \pm 11.4$ & $0.87 \pm 0.04$ \\
\hline $\begin{array}{l}\text { Normal wt } \\
\text { diabetic (12) }\end{array}$ & $65.1 \pm 5.1$ & $20.9 \pm 2.4$ & $0.32 \pm 0.02$ & $46.9 \pm 6.4$ & $0.72 \pm 0.09$ \\
\hline Obese diabetic (12) & $133.2 \pm 4.7$ & $27.9 \pm 4.1$ & $0.21 \pm 0.02$ & $74.3 \pm 8.0$ & $0.54 \pm 0.05$ \\
\hline
\end{tabular}

* Number of subjects.

$\ddagger$ All values represent mean \pm SEM.

jects to "normal" and "diabetic" blood glucose profiles are shown in Figs. 4 and 5 and Table II. The insulin secretory responses of normal weight diabetic individuals to a normal glucose profile $\left(565 \pm 108 \mu \mathrm{U}-\min \mathrm{ml}^{-1}\right.$ ) was less than $30 \%$ of that seen in normal subjects $(2088 \pm 146 \mu \mathrm{U}$-min $\mathrm{ml}^{-1}$ ). This was despite the fact that the infusion procedure consistently "overshot" the desired blood glucose levels at 60,90 , and $120 \mathrm{~min}$ in the diabetic group. A similar impairment in pancreatic insulin secretion of the normal weight diabetic group was also observed in response to a diabetic blood glucose profile $(7416 \pm 990$ vs. $2124 \pm 242 \mu \mathrm{U}-\mathrm{min} \mathrm{ml}^{-1}$ for normal and normal weight diabetics, respectively).

In both normal and diabetic subjects, obesity was associated with an excessive plasma insulin response to normal and diabetic infused blood glucose profiles. Obese diabetic subjects, however, exhibited significant impairment in insulin secretion when compared to their obese nondiabetic counterparts, the secretory response being 40 and $18 \%$ of the response seen in appropriate weight control subjects to normal and diabetic blood profiles, respectively. (Table II).

Glucose loads. The glucose load required to establish a normal glucose profile in normal weight diabetics $(0.32 \pm 0.02 \mathrm{~g} / \mathrm{kg})$ was at least $30 \%$ less than that required in normal subjects $(0.46 \pm$ $0.02 \mathrm{~g} / \mathrm{kg}$ ). Larger differences were observed in the loads needed to produce diabetic profiles : nor$\mathrm{mal}, 1.64 \pm 0.18 \mathrm{~g} / \mathrm{kg}$ vs. normal weight diabetics, $0.72 \pm 0.09 \mathrm{~g} / \mathrm{kg}$.

Although obese nondiabetic subjects were clas- sified as nondiabetic on the basis of a $100 \mathrm{~g}$ oral glucose tolerance test, the oral glucose load given these individuals, when expressed in terms of body weight $(0.69 \pm 0.07 \mathrm{~g} / \mathrm{kg})$ was significantly less than that ingested by the normal group $(1.41 \pm 0.14 \mathrm{~g} / \mathrm{kg})$. Further evidence that carbohydrate tolerance in these obese subjects is severely impaired is the fact that the infusion glucose loads required for normal $(0.25 \pm 0.05 \mathrm{~g} / \mathrm{kg})$ and diabetic $(0.87 \pm 0.04 \mathrm{~g} / \mathrm{kg})$ blood glucose profiles were comparable to those determined for normal weight diabetics $(0.32 \pm 0.02 \mathrm{~g} / \mathrm{kg}$ and $0.72 \pm$ $0.09 \mathrm{~g} / \mathrm{kg}$, respectively) and $40-50 \%$ of the load given normal individuals. The patients with the greatest impairment in carbohydrate tolerance appear to be the obese diabetics since the glucose loads necessary to duplicate normal and diabetic profiles $(0.21 \pm 0.02 \mathrm{~g} / \mathrm{kg}$ and $0.54 \pm 0.05 \mathrm{~g} / \mathrm{kg})$ were considerably less than that infused in normal weight diabetics.

\section{Discussion}

The original observations of Straub (10) and Traugott (11) over $45 \mathrm{yr}$ ago and the more recent studies of Conard (12), Dupré (13), and Somersalo (14) indicating that the oral but not intravenous administration of glucose increased the rate of utilization of a second glucose load led to the suggestion that the insulin secretory response differed quantitatively depending on the route of glucose administration. Evidence supporting this interpretation was first obtained by Elrick et al. (1) and McIntyre et al. $(2,3)$ who demonstrated that the plasma insulin responses to 
TABLE $\mathrm{V}$

Insulinogenic effectiveness of the alimentary and glycemic components of glucose-stimulated insulin secretion

\begin{tabular}{lccc}
\hline \hline & & \multicolumn{2}{c}{ Glycemic } \\
\cline { 3 - 4 } Subjects & Alimentary & $\begin{array}{c}\text { "Normal } \\
\text { profile" }\end{array}$ & $\begin{array}{c}\text { "Diabetic } \\
\text { profile" }\end{array}$ \\
\hline & & $\mu U-\min ~$ & $\mathrm{ml}^{-1} / \mathrm{g}$ of glucose \\
Normal & 54.9 & 65.5 & 64.1 \\
$\begin{array}{l}\text { Obese } \\
\text { Normal wt } \\
\text { diabetics }\end{array}$ & 170.6 & 210 & 226 \\
$\begin{array}{c}\text { Obese } \\
\text { diabetics }\end{array}$ & 33.5 & 27.1 & 46.5 \\
\hline
\end{tabular}

glucose given by either gastric (1) or jejunal intubation (2) were significantly greater than those seen after infusion of the same glucose loads despite the higher blood glucose levels attained during the latter procedures.

The experimental design used in the present study was selected for two reasons: $(a)$ to permit quantitation of the relative insulinogenic effects of the alimentary (i.e. oral glucose ingestion) and glycemic (i.e. blood glucose level) stimuli on beta cell secretion; and $(b)$ to examine these responses in various physiologic and pathologic conditions.

Our results clearly indicate that the plasma insulin response to an oral glucose load cannot be accounted for solely by the associated changes in the blood glucose level. Some mechanism triggered by the oral ingestion of glucose and independent of the peripheral blood sugar level must mediate in part the insulin response to an oral glucose load. It would appear that this alimentary mechanism, at least in the human, is located in the upper gastrointestinal tract and not in the hepato-portal system as suggested by Goetz et al. (15) since similar results are obtained in patients with diversion of their portal circulation. Our data further permit an estimate of the relative insulinogenic potencies of the alimentary and glycemic stimuli (Table V). The alimentary component was calculated by subtracting from the insulin secretory response seen after oral glucose that insulin response obtained with the infusion of glucose which duplicated the oral blood glucose profile. When expressed in terms of $\mu$ units-minutes $\mathrm{ml}^{-1}$ per gram of glucose, the insulinogenic potency in normal subjects of the alimentary stimulus $\left(54.9 \mu \mathrm{U}-\mathrm{min} \mathrm{ml}^{-1} / \mathrm{g}\right)$ and glycemic stimulus (64-65 $\mu \mathrm{U}-\min \mathrm{ml}^{-1} / \mathrm{g}$ ) are remarkably compar- able. A variety of enteric hormones including glucagon $(16,17)$, secretin (13), pancreozymin (18), and possibly other intestinal factors (19) have been reported to stimulate insulin secretion independently of changes in blood sugar. Whether only one or all of these substances function as the physiological mediator(s) of the alimentary component of oral glucose-stimulated insulin secretion remains to be determined.

There are few data in the literature concerning the disposition of an oral glucose load between hepatic uptake and utilization by the peripheral tissues in either man or laboratory animals. Scow and Cornfield (20) reported that, in the rat, approximately $60-65 \%$ of an oral glucose load was taken up by the liver, the remainder entering the systemic circulation. A similar disposition appears to occur in man. In the experimental design used in this study, the intravenous glucose load required to duplicate the oral blood glucose profile can be taken as a close approximation of the quantity of glucose escaping initial hepatic uptake after oral ingestion. In the normal individual, approximately $31 \mathrm{~g}$ of a $100 \mathrm{~g}$ oral glucose load enters the peripheral circulation (Table VI) and represents the glycemic component of the oral glucose insulinogenic stimulus. In the normal weight diabetic subject, on the other hand, over $50 \%$ of the oral glucose load enters the peripheral circulation and this value increases to in excess of $75 \%$ in the obese diabetic. Therefore, it is important to recognize that the insulinogenic stimulus of an oral glucose load is a multicomponent one which cannot be expressed simply in terms of the quantity of glucose ingested.

The evolution of an alimentary insulinogenic mechanism would contribute to the maintenance of metabolic homeostasis by insuring the immediate release of insulin coincident with glucose ingestion, thereby accelerating hepatic extraction of absorbed glucose and preventing excessive fluctuations of the peripheral blood sugar and insulin levels. The physiological significance of this insulinogenic mechanism is particularly evident in the diabetic individual. As is evident from Table $\mathrm{V}$, pancreatic beta cell secretory responsiveness to the alimentary stimulus is depressed in both normal weight and obese diabetics. This results in a less than normal initial increase in the portal vein insulin level which 
TABLE VI

Insulinogenic stimulus of a $100 \mathrm{~g}$ oral glucose load in normal and diabetic subjects

\begin{tabular}{|c|c|c|c|c|}
\hline \multirow[t]{2}{*}{ Subjects } & \multirow{2}{*}{$\begin{array}{c}\begin{array}{c}\text { Oral } \\
\text { glucose } \\
\text { load }\end{array} \\
g\end{array}$} & \multirow{2}{*}{$\begin{array}{c}\begin{array}{c}\text { i. v. glucose load } \\
\text { to reproduce oral } \\
\text { glucose profile* }\end{array} \\
g\end{array}$} & \multicolumn{2}{|c|}{$\begin{array}{l}\text { Glycemic stimulus } \\
\text { above control }\end{array}$} \\
\hline & & & $g$ & $\%$ \\
\hline Normal & 100 & $31.4 \pm 1.4 \ddagger$ & - & - \\
\hline Normal wt diabetic & 100 & $50.5 \pm 2.4$ & 19.1 & 62 \\
\hline Obese & 100 & $34.8 \pm 3.3$ & - & - \\
\hline Obese diabetic & 100 & $78.5 \pm 8.6$ & 43.7 & 120 \\
\hline
\end{tabular}

* Values for normal weight individuals corrected to $70 \mathrm{~kg}$ body weight and for obese individuals corrected to $140 \mathrm{~kg}$ body weight.

$\ddagger$ Values represent the mean \pm sEM.

is reflected in the delayed rise of peripheral plasma insulin characteristic of the maturity-onset diabetic (21). Since hepatic glucose uptake is an insulindependent process (22), a greater than normal proportion of an ingested glucose load will escape hepatic uptake in the diabetic and enter the peripheral circulation.

The excessive plasma insulin levels seen in many maturity-onset diabetics have been interpreted by some $(21,23)$ as indicating a hypersecretory responsiveness which has developed secondary to a state of insulin antagonism. The term hypersecretion denotes a greater than normal response to a given stimulus. An essential element in this definition is that the stimulus must be the same both qualitatively and quantitatively. Such is not the case for an oral glucose load given normal and diabetic individuals, as pointed out above, for although the alimentary stimulus is equivalent in both groups, the glycemic insulinogenic component is $60-120 \%$ greater in the diabetic subjects (Table VI). This difference in the glycemic component readily explains the excessive insulin levels seen in mild diabetics late in the course of an oral glucose tolerance test. When the insulin secretory response of normal and diabetic subjects to an equivalent glycemic stimulus is determined, im. paired insulin secretion is readily demonstrated in both the normal weight and obese diabetic groups (Figs. 4 and 5, Table II). Furthermore, the diabetic also exhibits a defective insulin response to the alimentary component, as shown in Table V. These results are in agreement with the conclusion recently reported by Seltzer et al. (24) and Cerasi and Luft (25) that insulin secretion is impaired in diabetes mellitus.

An example of true hypersecretory insulin re- sponsiveness is seen in association with obesity. In obese individuals, both nondiabetic and diabetic, the insulin responses to comparable alimentary and glycemic stimuli are two- to fourfold greater than those seen in nondiabetic and diabetic control subjects of normal weight (Table V). Similar results have been reported by Karam et al. (26) and have also been noted in response to tolbutamide (27) and arginine infusions (28).

The diabetic state does not appear to be associated with an impairment of the biological effectiveness of insulin. Thus, if insulin effectiveness is expressed in terms of a glucose load/insulin secretory response ratio, comparable values ranging from 0.015 to 0.022 are observed in both normal and normal weight diabetic subjects in response to infused normal and diabetic blood glucose profiles. In contrast, the values observed in both obese nondiabetic and diabetic subjects under similar conditions ranged from 0.004 to 0.010 , indicating the presence of significant insulin antagonism associated with obesity per se.

\section{References}

1. Elrick, H., L. Stimmler, C. J. Hlad, Jr., and Y. Arai. 1964. Plasma insulin response to oral and intravenous glucose administration. J. Clin. Endocrinol. Metab. 24: 1076.

2. McIntyre, N., C. D. Holdsworth, and D. S. Turner. 1965. Intestinal factors in the control of insulin secretion. J. Clin. Endocrinol. Metab. 25 : 1317.

3. McIntyre, N., C. D. Holdsworth, and D. S. Turner. 1964. New interpretation of oral glucose tolerance. Lancet. 2: 20.

4. Balsano, F., G. Pitucco, A. Musca, and V. Di Noto. 1964. New interpretation of oral glucose tolerance. Letters to the editor. Lancet. 2: 865 .

5. Somogyi, M. Determination of blood sugar. 1945. J. Biol. Chem. $160: 69$. 
6. Weller, C., M. Linder, A. Macduloy, A. Ferrari, and G. Kessler. 1960. Continuous in vivo determination of blood glucose in human subjects. $A n n$. N. Y. Acad. Sci. 87 : 658.

7. Burns, T. W., R. Bregant, H. J. Van Peenon, and T. E. Hood. 1965. Observations on blood glucose concentration of human subjects during continuous sampling. Diabetes. 14: 186.

8. Kipnis, D. M., E. Helmreich, and C. F. Cori. 1959. Studies of tissue permeability. IV. The distribution of glucose between plasma and muscle. $J$. Biol. Chem. 234: 165.

9. Morgan, C. R., and A. Lazarow. 1963. Immunoassay of insulin: two antibody system. Diabetes. 12 : 115.

10. Straub, H. 1921. Untersuchungen über den zuckerstoffwechsel des menschen. I. Mitteilung: Uber dos Verhalten des Blutzucker nach peroraler $\mathrm{Zu}$ fuhr kleiner Glukosemengen. Z. Klin. Med. $91: 44$.

11. Traugott, K. 1922. Ueber das Verhalten des Blutzuckerspiegels bei wiederholter und verschiedener Art enteraler Zuckerzufuhr und dessen Bedeutung für die Leberfunktion. Klin. Wochshr. 1: 892.

12. Conard, V. 1955. Mesure de l'assimilation du glucose; bases théoreques et applications clineques. Acta Medica Belgica. Bruxelles. 1.

13. Dupré, J. 1964. An intestinal hormone affecting glucose disposal in man. Lancet. 2: 672.

14. Somersalo, O. 1950. Staub effect in children. Studies of the blood sugar regulation by means of double and triple glucose tolerance tests. Acta Paediat., Suppl. 78.

15. Goetz, F. C., J. W. Money, and B. Z. Greenberg. 1963. An extrapancreatic mechanism for insulin release. J. Lab. Clin. Med. 62: 877. (Abstr.)

16. Samols, E., G. Marri, and V. Marks. 1965. Promotion of insulin secretion by glucagon. Lancet. 2 : 415.

17. Ketterer, H., A. M. Eisentraut, and R. H. Unger. 1967. Effect upon insulin secretion of physiologic doses of glucagon administered via the portal vein. Diabetes. 16 : 283.

18. Meade, R. C., H. A. Kneubuhler, W. J. Schulte, añd
J. J. Barboriak. 1967. Stimulation of insulin secretion by pancreozymin. Diabetes. 16: 141.

19. Ketterer, H., J. Dupré, A. M. Eisentraut, and R. H. Unger. 1966. Insulin-releasing factors of the gastrointestinal tract. Diabetes. 15: 522 . (Abstr.)

20. Scow, R. O., and J. Cornfield. 1954. Quantitative relations between oral and intravenous glucose tolerance curves. Am. J. Physiol. $179: 435$.

21. Yalow, R. S., and S. A. Berson. 1960. Plasma insulin concentrations in nondiabetic and early diabetic subjects. Diabetes. 9: 254.

22. Madison, L. L., and R. H. Unger. 1958. The physiologic significance of the secretion of endogenous insulin into the portal circulation. I. Comparison of the effects of glucagon-free insulin administered via the potral vein and via a peripheral vein on the magnitude of hypoglycemia and peripheral glucose utilization. J. Clin. Invest. 12: 631 .

23. Yalow, R. S., S. M. Glick, J. Roth, and S. A. Berson. 1965. Plasma insulin and growth hormone levels in obesity and diabetes. Ann. N.Y.Acad. Sci. 131 : 357.

24. Seltzer, H. S., E. W. Allen, A. L. Herron, Jr., and M. T. Brennan. 1967. Insulin secretion in response to glycemic stimulus: Relation of delayed initial release to carbohydrate intolerance in mild diabetes mellitus. J. Clin. Invest. 46: 323.

25. Cerasi, E., and R. Luft. 1967. The plasma insulin response to glucose infusion in healthy subjects and in diabetes mellitus. Acta Endocrinol. 55: 278.

26. Karam, S. A., F. C. Pavlatos, G. M. Grodsky, and P. H. Forsham. 1965. Critical factors in excessive serum-insulin response to glucose. Obesity in maturity-onset diabetes and growth hormone in acromegaly. Lancet. 1: 286.

27. Perley, M., and D. M. Kipnis. 1966. Plasma insulin responses to glucose and tolbutamide of normal weight and obese diabetic and nondiabetic subjects. Diabetes. 15 : 867.

28. Rabinowitz, D., T. J. Merimee, J. K. Nelson, R. B. Schultz, and L. Riggs. 1967. Hormonal profile of obesity. Trans. Assoc. Am. Physicians. 80: in press. 